\title{
A Dominance Modifier for Cycloheximide Resistance in Coprinus cinereus
}

\author{
By JANE NORTH \\ Department of Biological Sciences, City of London Polytechnic, Calcutta House, \\ London EI $7 N T$, U.K.
}

(Received 27 January 1982; revised 4 May 1982)

Wild and laboratory strains of Coprinus cinereus show varying levels of sensitivity to cycloheximide (actidione). Mutants resistant to $1.0 \mu \mathrm{g}$ cycloheximide $\mathrm{ml}^{-1}$ were isolated from UV light-irradiated oidia of two strains unable to grow on more than $0.25 \mu \mathrm{g}$ cycloheximide $\mathrm{ml}^{-1}$. Of 13 induced mutants, 12 fell into one complementation group, $c y-2$; mutants at this locus were usually recessive, but one of those isolated carried a dominance modifier gene, modcy which led to partial resistance in dikaryons heterozygous for $c y-2 r$. Modcy $y^{+}$was dominant in dikaryons to its non-mutant allele modcy-, but it had no effect in diploids. However, it affected all $c y-2^{r}$ alleles tested in dikaryons. Linkage data are presented for $c y-2, \bmod c y$ and another cycloheximide resistance gene, $c y-1$, which is found in wild strains.

\section{INTRODUCTION}

Cycloheximide is a glutarimide antibiotic which is toxic to eukaryotic cells, having its major effect on protein synthesis (Sisler \& Siegel, 1967). Mutants resistant to this antibiotic have been isolated in several fungi, including Neurospora crassa (Hsu, 1963; Neuhäuser et al., 1970), Saccharomyces cerevisiae (Wilkie \& Lee, 1965), Saccharomyces fragilis (Siegel \& Sisler, 1965), Schizosaccharomyces pombe (Ibrahim \& Coddington, 1976), Schizophyllum commune (Pikálek \& Necásek, 1978) and Podospora anserina (Crouzet et al., 1978). In all these species, except Schizophyllum commune, mutants with altered cytoplasmic ribosomes have been identified, although other mechanisms of resistance, for instance detoxification or impermeability, have also been discovered.

Coprinus cinereus is a basidiomycete fungus with a monokaryotic and a dikaryotic stage in its life cycle; stable diploids can be produced artificially (Casselton, 1965). It is therefore possible to study genetic interactions within and between nuclei in this organism: cycloheximide resistance due to an altered ribosomal component could be used as a label for the ribosomes produced by one type of nucleus in a dikaryon.

This paper describes the isolation of cycloheximide-resistant mutants in C. cinereus and some of their properties in dikaryons and diploids. A preliminary report of these results has been made (North, 1978).

\section{METHODS}

Culture media. These were described by Lewis \& North (1974): glucose was sterilized separately and added (at $1 \%, w / v)$ after the medium had been autoclaved. Supplements to the medium were added at the usual concentrations (Lewis, 1961). Fruit bodies were grown on agar plates or sterile horse manure.

Materials. Cycloheximide (actidione) was supplied by Koch-Light. Difco Bacto-agar was used throughout. Other materials were purchased from the usual suppliers.

Strains and nomenclature. The strains of Coprinus cinereus used in mutagenesis and genetic analysis are listed in Table 1. Apart from the ftr marker strain ZR197 40/40, the strains were derived from a wild cycloheximideresistant strain TC4 and the multiply-marked cycloheximide-sensitive strains SR54 and WMR66A, which have a 
Table 1. Strains of $C$. cinereus used in this investigation

\begin{tabular}{|c|c|c|c|c|}
\hline Strain & Mating type & Markers & $\begin{array}{l}\text { Cycloheximide } \\
\text { resistance } \\
\text { status }\end{array}$ & Origin \\
\hline TC4 & $A_{5} B_{5}$ & & $c y-I^{r}$ & Wild strain (H series)* \\
\hline WMR66A & $A_{6} B_{6}$ & $n i c-4 p a b a-2$ & $c y^{s}$ & Multiple crosses \\
\hline SR54 & $A_{6} B_{6}$ & ad-8 me-5 chol-1 & $c y^{5}$ & Multiple crosses \\
\hline CY2 & $A_{5} B_{6}$ & $m e-5$ chol-1 & $c y-r^{r}$ & Basidiospore progeny of \\
\hline CY3 & $A_{5} B_{5}$ & $m e-5$ chol-1 & $c y^{s}$ & $\begin{array}{l}\text { Basidiospore progeny or } \\
\text { TC4 } \times \text { SR 54 }\end{array}$ \\
\hline CY5 & $A_{6} B_{5}$ & ad-8 chol-1 & $c y-I^{r}$ & \\
\hline CY6 & $A_{5} B_{5}$ & nic-4 paba-2 & $c y^{5}$ & \\
\hline CY8 & $A_{6} B_{5}$ & nic-4 paba-2 & $c y^{s}$ & Basidiospore progeny of \\
\hline CY9 & $A_{6} B_{6}$ & nic-4 paba-2 & $c y^{s}$ & TC4 $\times$ WMR66A \\
\hline CY11 & $A_{5} B_{6}$ & nic-4 paba-2 & $c y^{s}$ & \\
\hline CY13 & $A_{5} B_{6}$ & me-5 chol-1 & $c y^{s}$ & Basidiospore progeny of \\
\hline CY14 & $A_{6} B_{5}$ & ad-8 me-5 chol-1 & $c y^{s}$ & $\mathrm{TC} 4 \times \mathrm{SR} 54$ \\
\hline ZR $19740 / 40$ & $A_{40} B_{40}$ & $f t r$ & $c y^{s}$ & $\begin{array}{l}\text { Basidiospore progeny of } \\
\text { mutant and wild strain } \\
\text { from Czechoslovakia } \dagger^{\dagger}\end{array}$ \\
\hline
\end{tabular}

* H series described by Lewis \& North (1974).

$\dagger$ Origin described by Moore \& Stewart (1971).

complex origin. Basidiospore progeny from crosses of TC4 with SR54 or WMR66A were numbered CY1, CY2 and so on.

Mutants isolated from CY strains were numbered according to their parent strain, for example CY9.23 was derived from CY9. Recombinant progeny from the cross between $\mathrm{CY} 9.23$ and $\mathrm{CY} 3$ are referred to by spore isolate numbers, e.g. Sp78.

Dikaryons, whose formation is reversible, are described in the same way as a cross: CY9.23 $\times$ CY3. Diploids are lettered CYD followed by the numbers of their constituent strains, for instance CYD9/14 was made from CY9 and CY14.

Cycloheximide resistance and sensitivity alleles are represented by $c y-I^{r}, c y-I^{s}$, respectively; the presence of an active dominance modifier allele is represented by $\operatorname{modcy}^{+}$and its wild-type non-active allele by modcy .

Genetic analysis. Dominance and complementation tests in dikaryons and meiotic mapping were carried out as described by Lewis (1961). Diploids were selected by the method of Casselton (1965) and their diploidy confirmed using a dikaryon test, which involves mating to a strain of such genotype that a prototrophic dikaryon can only be formed if the tested strain is a diploid (C. Casselton, personal communication). Mitotic mapping was carried out by using griseofulvin (North, 1977).

Mutagenesis and selection of cycloheximide-resistant mutants. Mutations were induced in oidia of CY9 and CY11 using a Hanovia UV light giving a dose of $0.65 \mu \mathrm{J} \mathrm{cm}{ }^{-2}$. Irradiation of an oidial suspension for 7 min reduced the viability of the spores to about $3 \%$ of the unirradiated level; the mutation rate to cycloheximide resistance was 1-2 $\times 10^{-6}$.

The expression of cycloheximide resistance requires de novo synthesis of mutant cellular components (Neuhäuser et al., 1970; Brusick, 1972). In order to allow such expression, mutagenized oidia were plated on complete medium and incubated at $37^{\circ} \mathrm{C}$ for $36 \mathrm{~h}$ before overlayering with $1 \%$ water agar containing $15 \mu \mathrm{g}$ cycloheximide $\mathrm{ml}^{-1}$. Overlayered plates were incubated for 14-21 d, after which colonies that had grown through to the top were isolated on to complete medium. On testing, the majority of colonies isolated proved to be stable mutants able to grow on at least $1 \mu \mathrm{g}$ cycloheximide $\mathrm{ml}^{-1}$.

Growth tests. Growth was measured on solid medium after $72 \mathrm{~h}$ incubation at $37^{\circ} \mathrm{C}$. Initially, resistance to cycloheximide was scored as the ability to grow on medium containing $1.0 \mu \mathrm{g}$ cycloheximide $\mathrm{ml}^{-1}$ (haploid and diploid monokaryons) or $0.5 \mu \mathrm{g}$ cycloheximide $\mathrm{ml}^{-1}$ (dikaryons). Later, more detailed tests were used to determine the maximum concentration of cycloheximide permitting growth. Two or more replicates were set up for each test; tests were repeated several times.

\section{RESULTS}

\section{Resistance of wild strain TC4 to cycloheximide}

Strains WMR66A and SR54 are both unable to grow on $0 \cdot 1 \mu \mathrm{g}$ cycloheximide $\mathrm{ml}^{-1}$. Crosses of these strains to TC4, which can grow on $1.0 \mu \mathrm{g}$ cycloheximide $\mathrm{ml}^{-1}$, indicated that this level of resistance was due to a single gene, designated $c y-1^{r}$. 


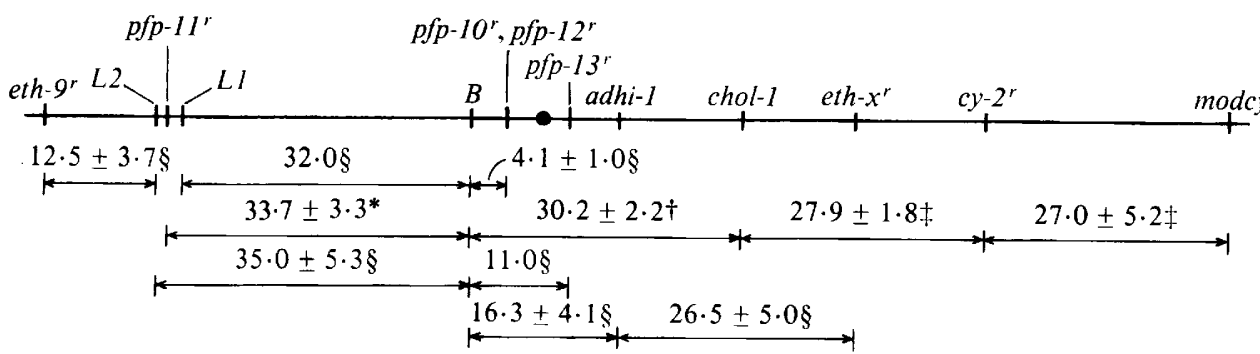

Fig. 1. Genetic map of linkage group II of Coprinus cinereus. References: *, Senathirajah \& Lewis (1975); †, Lewis \& North (1974); $\ddagger$, this paper; $\S$, Jehan (1979).

Table 2. Growth of strains carrying the cy-1r and cy-1s alleles

\begin{tabular}{|c|c|c|}
\hline Strain & $\begin{array}{l}\text { Genotype } \\
(c y-1)\end{array}$ & $\begin{array}{l}\text { Maximum cycloheximide concn. } \\
\text { permitting growth }\left(\mu \mathrm{g} \mathrm{ml}^{-1}\right)\end{array}$ \\
\hline CY8 & $s]$ & $0 \cdot 3$ \\
\hline CY6 & $s$ & $0 \cdot 1$ \\
\hline CY2 & monokaryons & $2 \cdot 0$ \\
\hline CY5 & $\mathrm{E}$ & $1 \cdot 0$ \\
\hline TC4 & $r J$ & 3.0 \\
\hline $\mathrm{CY} 2 \times \mathrm{CY} 8$ & $r \times s$ dikaryon & $2 \cdot 0$ \\
\hline CYD2/6 & $r / s$ diploid & $1 \cdot 0$ \\
\hline
\end{tabular}

The $c y-I^{r}$ allele was dominant in dikaryons and diploids. Tests among the progeny of SR54 $\times$ TC4 and WMR66A $\times$ TC4 showed no segregation of dominance from resistance, indicating that no dominance modifier genes were involved (Table 2).

Analysis of the progeny of ZR $19740 / 40$ and TC4 indicated that $c y-1$ is $36 \cdot 5 \pm 4 \cdot 5$ units from ftr on linkage group VII.

\section{$U V$-induced mutants resistant to cycloheximide}

Mutants were selected from CY9 and CY11 as described in Methods. Mutants from CY9 were tested for dominance in dikaryons with CY3; those from CY11 were tested with CY14. All the mutants were recessive except for CY9.23, which showed a partial dominant phenotype: the dikaryon CY9.23 $\times$ CY3 could grow on minimal medium plus $0.5 \mu \mathrm{g}$ cycloheximide $\mathrm{ml}^{-1}$ and could fruit on this medium. This dikaryon was allowed to fruit, and the basidiospores were tested for resistance to $1.0 \mu \mathrm{g}$ cycloheximide $\mathrm{ml}^{-1}$ and for dominance of cycloheximide resistance. Certain of the basidiospores were shown to carry cycloheximide resistance which was recessive in the dikaryon, indicating that CY9.23 carried a dominance modifier gene, designated modcy . Sensitive progeny carrying the modifier gene were identified by their ability to form partially resistant dikaryons with unmodified resistant strains, indicating that the modifier can act in trans. Dikaryons between CY9 and unmodified resistant strains were sensitive, showing that the modifier gene is a new mutation not found in the original CY9 strain, which is therefore modcy-.

Complementation testing indicated that all except one of the mutants isolated were allelic. There were two cases of apparent interallelic complementation, both involving mutant CY9.24. The two resistance loci identified were designated $c y-2$ ( 12 isolates) and $c y-3$ ( 1 isolate). The only $c y-3$ strain isolated was a weak mutant; tests for mitotic and meiotic linkage failed to show association with markers on groups I, II, IV, VI and VII. No further work was carried out with this strain.

\section{Linkage relationships of $c y-2$ and modcy}

$c y-2$ showed linkage with the $c h o l-1$ locus, which is linked to the $B$ mating-type locus on group II (Lewis \& North, 1974). Recombination values for crosses involving five $c y-2^{r}$ alleles were statistically homogeneous; the combined data gave the map position of $c y-2$ as $27.9 \pm 1.8$ units distal to chol-1 (Fig. 1). 
Table 3. Growth on cycloheximide of dikaryons heterozygous for cy-2 alleles with and without modcy ${ }^{+}$

Key: +++ , no inhibition; ++ , good growth; + , poor growth; \pm , very slight growth; - , no growth; ND, not determined.

\begin{tabular}{|c|c|c|c|}
\hline \multirow{2}{*}{$\begin{array}{l}c y-2^{r} \text { mutant } \\
\text { Cycloheximide concn ... }\end{array}$} & \multirow{2}{*}{$\begin{array}{l}\text { Dikaryon with } \\
c y-2^{s} \text { modcy- } \\
0.5 \mu \mathrm{g} \mathrm{ml}^{-1}\end{array}$} & \multicolumn{2}{|c|}{ Dikaryon with $c y-2^{s}$ modcy ${ }^{+}$} \\
\hline & & $0.5 \mu \mathrm{g} \mathrm{ml}^{-1}$ & $1.0 \mu \mathrm{g} \mathrm{ml}^{-1}$ \\
\hline CY9.1 & - & +++ & \pm \\
\hline CY9.21 & - & ++ & \pm \\
\hline CY9.24 & - & ++ & \pm \\
\hline CY9.25 & - & ++ & \pm \\
\hline CY 11.30 & - & + & \pm \\
\hline CY11.34 & - & + & \pm \\
\hline CY 11.35 & - & + & \pm \\
\hline Sp137 $\left(c y-2^{r} \bmod c y^{-}\right)^{*}$ & - & ++ & $\overline{+}$ \\
\hline CY $9.23 \times C Y 3$ & ND & ++ & \pm \\
\hline
\end{tabular}

Analysis of a cross between CY9.23 $\left(c y-2^{r}\right.$ modcy $\left.y^{+}\right)$and CY3 $\left(c y-2^{s} \bmod c y^{-}\right)$indicated that modcy is also on group II, $27 \cdot 0 \pm 5 \cdot 2$ units distal to $c y-2$. Senathirajah \& Lewis (1975) reported that the $p$-fluorophenylalanine resistance locus $p f p-11^{r}$ and its linked modifier gene are also on group II. A cross between a $c y-2^{s} p f p-11^{r}$ strain and a $c y-2^{r} p f p-11^{s}$ strain showed that these two loci recombine freely; the $p f p-11$ locus is therefore on the other arm of group II from chol-1 and $c y-2$. The linkage relationships of the resistance loci reported to be on Group II will be presented in the Discussion.

\section{Specificity of the modcy gene}

Strains carrying modcy and $c y-s$ were used to make dikaryons with alleles of $c y-2^{r}$ other than the CY9.23 allele. Dikaryons were tested for their ability to grow on 0.5 and $1.0 \mu \mathrm{g}$ cycloheximide $\mathrm{ml}^{-1}$. The results, shown in Table 3, indicate that the modcy $y^{+}$gene confers partial resistance in dikaryons heterozygous for a variety of $c y-2^{r}$ alleles, and it is therefore not allele specific. It is interesting to note that although the mutants used in the test cannot grow on more than $2 \cdot 0 \mu \mathrm{g}$ cycloheximide $\mathrm{ml}^{-1}$, the resistance of the modified dikaryons is comparable with CY9.23 $\times$ CY3, where CY 9.23 can grow on $250 \mu \mathrm{g}$ cycloheximide $\mathrm{ml}^{-1}$.

\section{Effect of the cy-2r modifier gene in dikaryons and diploids}

Basidiospores isolated from the cross CY9.23 $\times$ CY3 were used to construct dikaryons and diploids with various constitutions with respect to the $c y-2^{r}$ allele and its modifier. Because of the linkage of the genes to the $B$ mating-type allele and the need for complementary forcing markers to make diploids, some combinations were not possible.

Growth tests were set up on minimal medium for most diploids and dikaryons: those with auxotrophic requirements (denoted $\ddagger$ in Table 4 ) were tested on complete medium, as were the monokaryons, except CY9.23 $\times$ CY3 basidiospore progeny Sp137 and Sp34 that were prototrophs tested on minimal medium.

Table 4 shows the maximum concentration of cycloheximide permitting growth for each genotype. It is clear from these results that there is variation in the level needed to inhibit growth of the strains originally designated sensitive due to their inability to grow on $1.0 \mu \mathrm{g}$ cycloheximide $\mathrm{ml}^{-1}$. This variation is seen in $c y-2^{s}$ modcy $y^{+}$and $c y-2^{s}$ modcy- strains; however, the difference between the $c y-2^{r}$ and $c y-2^{s}$ monokaryons is clear. The presence of the modifier gene has no effect on the level of resistance of the $c y-2^{r}$ monokaryons, which also vary in their resistance levels. As indicated by the preliminary results, homozygous resistant dikaryons have a lower tolerance to cycloheximide than resistant haploid monokaryons, but homozygous resistant diploids are similar to resistant haploids.

In sensitive dikaryons, both $c y-2^{s} \times c y-2^{s}$ and $c y-2^{s} \operatorname{modcy} y^{-} \times c y-2^{r}$ modcy-, the level of 
Table 4. Properties of monokayons, dikaryons and diploids with and without cy-2r and its modifier gene

\begin{tabular}{|c|c|c|c|c|c|c|}
\hline \multirow{3}{*}{$\begin{array}{c}\text { Genotype } \\
\text { combination* } \\
s-s-\end{array}$} & \multirow{2}{*}{\multicolumn{2}{|c|}{$\begin{array}{l}\text { Component } \\
\text { strains } \dagger\end{array}$}} & \multicolumn{4}{|c|}{ Maximum cycloheximide tolerance $\left(\mu \mathrm{g} \mathrm{ml}^{-1}\right)$} \\
\hline & & & \multicolumn{2}{|c|}{ Haploids } & \multirow{2}{*}{$\begin{array}{c}\text { Dikaryon } \\
0.010 \\
0.015\end{array}$} & \multirow[t]{2}{*}{ Diploid } \\
\hline & $\begin{array}{l}\text { CY9 } \\
\text { CY11 }\end{array}$ & $\begin{array}{l}\text { CY3 } \\
\text { CY14 }\end{array}$ & $\begin{array}{l}0 \cdot 250 \\
0 \cdot 200\end{array}$ & $\begin{array}{l}0.040 \\
0 \cdot 020\end{array}$ & & \\
\hline & & CY14 & $0 \cdot 250$ & $0 \cdot 020$ & & $0 \cdot 500$ \\
\hline$s-s+$ & $\begin{array}{l}\text { CY11 } \\
\text { CY6 } \\
\text { CY9 }\end{array}$ & $\begin{array}{l}\text { Sp24 } \\
\text { Sp34 } \\
\text { Sp39 }\end{array}$ & $\begin{array}{l}0 \cdot 200 \\
0 \cdot 100 \\
0 \cdot 250\end{array}$ & $\begin{array}{c}0 \cdot 200 \\
0 \cdot 100 \\
\text { ND }\end{array}$ & $\begin{array}{l}0 \cdot 250 \\
0.030\end{array}$ & 0.050 \\
\hline$s+s+$ & Sp34 & Sp135 & $0 \cdot 100$ & 0.060 & $0 \cdot 050$ & \\
\hline$s-r-$ & $\begin{array}{l}\text { CY9 } \\
\text { CY9 }\end{array}$ & $\begin{array}{l}\text { Sp137 } \\
\text { Sp20 }\end{array}$ & $\begin{array}{l}0 \cdot 250 \\
0 \cdot 250\end{array}$ & $\begin{array}{l}60 \\
50\end{array}$ & $0 \cdot 100$ & $0 \cdot 300$ \\
\hline$s-r+$ & $\begin{array}{l}\text { CY3 } \\
\text { CY9 } \\
\text { CY14 } \\
\text { CY14 }\end{array}$ & $\begin{array}{l}\text { CY9.23 } \\
\text { Sp48 } \\
\text { Sp138 } \\
\text { CY9.23 }\end{array}$ & $\begin{array}{l}0.040 \\
0.250 \\
0.020 \\
0.020\end{array}$ & $\begin{array}{r}250 \\
70 \\
50 \\
250\end{array}$ & $\begin{array}{l}1.0 \\
3.0 \ddagger \\
5 \cdot 0 \ddagger\end{array}$ & $0 \cdot 600$ \\
\hline$s+r-$ & $\begin{array}{l}\text { Sp34 } \\
\text { Sp78 } \\
\text { Sp102 }\end{array}$ & $\begin{array}{l}\text { Sp137 } \\
\text { Sp137 } \\
\text { Sp137 }\end{array}$ & $\begin{array}{l}0 \cdot 100 \\
0 \cdot 400 \\
0 \cdot 350\end{array}$ & $\begin{array}{l}60 \\
60 \\
60\end{array}$ & $\begin{array}{l}3.5 \\
5.0 \\
5.0\end{array}$ & \\
\hline$s+r+$ & $\begin{array}{l}\text { Sp78 } \\
\text { Sp34 } \\
\text { Sp102 }\end{array}$ & $\begin{array}{l}\text { Sp48 } \\
\text { Sp48 } \\
\text { Sp53 }\end{array}$ & $\begin{array}{l}0 \cdot 400 \\
0 \cdot 100 \\
0 \cdot 350\end{array}$ & $\begin{array}{l}70 \\
70 \\
70\end{array}$ & $\begin{array}{l}5 \cdot 0 \ddagger \\
5 \cdot 0\end{array}$ & 0.300 \\
\hline$r-r-$ & $\begin{array}{l}\text { Sp137 } \\
\text { Sp137 }\end{array}$ & $\begin{array}{l}\text { Sp91 } \\
\text { Sp98 }\end{array}$ & $\begin{array}{l}60 \\
60\end{array}$ & $\begin{array}{r}70 \\
150\end{array}$ & $\begin{array}{l}15 \cdot 0 \\
20 \cdot 0\end{array}$ & \\
\hline$r-r+$ & $\begin{array}{l}\text { Sp137 } \\
\text { Sp43 }\end{array}$ & $\begin{array}{l}\text { CY9.23 } \\
\text { CY } 9.23\end{array}$ & $\begin{array}{l}60 \\
70\end{array}$ & $\begin{array}{l}250 \\
250\end{array}$ & $10 \cdot 0$ & $150 \ddagger$ \\
\hline$r+r+$ & $\begin{array}{l}\text { CY9.23 } \\
\text { Spl38 } \\
\text { Sp138 }\end{array}$ & $\begin{array}{l}\text { Sp48 } \\
\text { Sp53 } \\
\text { Sp48 }\end{array}$ & $\begin{array}{r}250 \\
50 \\
50\end{array}$ & $\begin{array}{l}70 \\
70 \\
70\end{array}$ & $\begin{array}{l}20 \cdot 0 \ddagger \\
20 \cdot 0\end{array}$ & 70 \\
\hline
\end{tabular}

$\mathrm{ND}$, Not determined exactly (haploid strain lost); less than $1.0 \mu \mathrm{g} \mathrm{ml}^{-1}$.

* Genotypes: resistance and sensitivity to cycloheximide (cy-2 locus) are indicated by $r$ and $s$ respectively; presence and absence of an active modifier allele $(\bmod c y)$ are indicated by + and - respectively.

$\dagger \mathrm{Sp}$ indicates basidiospore progeny isolated from CY $9.23 \times \mathrm{CY} 3$.

$\ddagger$ Indicates an auxotrophic diploid or dikaryon tested on complete medium.

resistance resembles the more sensitive parent, except for $\mathrm{CY} 6 \times \mathrm{Sp} 34$, which is more sensitive. In dikaryons heterozygous for $c y-2^{r}$ the effect of a single or double dose of modcy+ is to increase the level of resistance 10-200-fold. This effect is not seen in $c y-2 r / c y-2^{s}$ diploids, even when these are homozygous for $\bmod c y^{+}$.

\section{DISCUSSION}

The cy-2 gene product

Preliminary results indicate that $c y-2^{r}$ strains have cycloheximide-resistant ribosomes (Traynor \& North, 1981): this implies that $c y-2$ codes for a ribosomal component. As there were examples of interallelic complementation among $c y-2^{r}$ mutants, it is likely that this gene specifies a multimeric protein. Experiments to identify the altered protein are in progress; cycloheximide resistance in other fungi has been shown to be a consequence of such a change (Coddington \& Fluri, 1977; Bégueret et al., 1977; Stöcklein \& Piepersberg, 1980).

\section{Modification of dominance by modcy ${ }^{+}$}

Dominance modifier genes affecting resistance to $p$-fluorophenylalanine and other inhibitors in C. cinereus have been described (Senathirajah \& Lewis, 1975; Jehan, 1979); in some cases the 
$\bmod ^{+}$genes are present in wild-type strains. In $C$. cinereus dikaryons, nuclear distribution is regular, with one nucleus of each type in each cell; this contrasts with the uneven distribution in heterokaryons (Casselton \& Lewis, 1967). Lewis \& Vakeria (1977) have suggested that the $p f p-10$ locus of $C$. cinereus codes for a multimeric protein. They propose that the dominance modifier $\bmod -10^{+}$allele favours the formation of $r$ homomultimers. The modcy $y^{+}$gene, which is present as an induced mutation in CY9.23, is a dominant, allele non-specific enhancer of cycloheximide resistance in dikaryons.

Kacser \& Burns (1981) suggest that dominance modifications may be a result of the interaction of proteins involved in a pathway. A protein required for assembly of Escherichia coli ribosomes, but not for their activity, has been reported by Nowotny \& Nierhaus (1980). I suggest that modcy codes for a protein involved in the pathway of ribosome assembly by affecting $c y-2$ multimer formation. In the dikaryon, modcy ${ }^{+}$is dominant in cis and trans, working by facilitating homomultimer assembly in or near its own nucleus, acting in a similar way to the $\bmod -10^{+}$gene referred to above, which is also dominant in dikaryons and without effect in diploids (Senathirajah \& Lewis, 1975). The modcy gene product may be a structural part of the ribosome, or its presence may only be necessary during the assembly process, like the bacterial protein mentioned above; its activity may not be locus specific.

\section{Linkage relationships in linkage group II}

Senathirajah \& Lewis (1975) and Jehan (1979) have reported resistance genes on group II, where $c y-2$ and modcy are located. $P f p-11$ is not linked to $c y-2$; however, the clustering of these genes on one linkage group is of interest and $I$ have taken this opportunity to collate and show, in Fig. 1, a summary of the present genetic map for this group.

\section{REFERENCES}

Bégueret, J., Perrot, M. \& Crouzet, M. (1977). Ribosomal proteins in the fungus Podospora anserina: evidence for an electrophoretically altered $60 \mathrm{~S}$ protein in a cycloheximide resistant mutant. Molecular and General Genetics 156, 141-144.

BRUSICK, D. J. (1972). Induction of cycloheximideresistant mutants in Saccharomyces cerevisiae with $N$ methyl- $N^{\prime}$-nitro- $N$-nitrosoguanidine and ICR-170. Journal of Bacteriology 109, 1134-1138.

Casselton, L. A. (1965). The production and behaviour of diploids of Coprinus lagopus. Genetical Research 6, 190-208.

Casselton, L. A. \& Lewis, D. (1967). Dilution of gene products in the cytoplasm of heterokaryons in Coprinus lagopus. Genetical Research 9, 63-71.

CODdington, A. \& FLuRI, R. (1977). Characterisation of the ribosomal proteins from Schizosaccharomyces pombe by two-dimensional polyacrylamide gel electrophoresis. Demonstration that a cycloheximide resistant strain, cyh-1, has an altered $60 \mathrm{~S}$ ribosomal protein. Molecular and General Genetics 158, 93-100.

Crouzet, M., Perrot, M., Nogueira, M. \& BÉGUERET, J. (1978). Genetic and biochemical analysis of cycloheximide resistance in the fungus Podospora anserina. Biochemical Genetics 16, 271286.

Hsu, K. S. (1963). The genetic basis of actidione resistance in Neurospora. Journal of General Microbiology 32, 341-347.

IBRAHIM, M. A. K. \& Coddington, A. (1976). Genetic studies on cycloheximide-resistant strains of Schizosaccharomyces pombe. Heredity 37, 179-191.
JEHAN, M. (1979). Dominant resistance to p-fluorophenylalanine and ethionine in Coprinus lagopus. Ph.D. thesis, University of London, U.K.

Kacser, H. \& BurNS, J. A. (1981). The molecular basis of dominance. Genetics 97, 639-666.

LEwIS, D. (1961). Genetical analysis of methionine suppressors in Coprinus lagopus. Genetical Research 2 , 141-155.

LEWIS, D. \& NoRTH, J. (1974). Linkage maps of Coprinus lagopus. In Handbook of Microbiology vol. 4, pp. 691-699. Edited by A. I. Laskin \& H. Lechevalier, Cleveland, Ohio: CRC Press.

Lewis, D. \& VakerIa, D. (1977). Resistance to pfluorophenylalanine in diploid/haploid dikaryons: dominance modifier gene explained as a controller of hybrid multimer formation. Genetical Research 30, 31-43.

MoORe, D. \& Stewart, G. R. (1971). Mutants of Coprinus lagopus selected for resistance to 2-deoxy-Dglucose. Genetical Research 18, 341-352.

NeUHÄUSER, A., KLINGMÜlleR, W. \& KAUdEWITZ, F. (1970): Selection Actidion-resistenter Mutanten bei Neurospora crassa sowie ihre genetische und biochemische Analyse. Molecular and General Genetics 106, 180-194.

NORTH, J. (1977). The effects of griseofulvin on diploid strains of Coprinus lagopus. Journal of General Microbiology 98, 529-534.

NORTH, J. (1978). Modification of dominance of a cycloheximide resistance mutation in Coprinus cinereus. Heredity 40, 331.

Nowotny, V. \& Nierhaus, K. H. (1980). Protein L20 from the large subunit of Escherichia coli ribosomes is 
an assembly protein. Journal of Molecular Biology 137, 391-399.

PikáleK, P. \& NecásaeK, J. (1978). Detoxication of cycloheximide by resistant strains of Schizophyllum commune. Folia microbiologica 23, 84-87.

Senathirajah, S. \& Lewis, D. (1975). Resistance to amino-acid analogues in Coprinus: dominance modifiers and dominance reversal in diploids and dikaryons. Genetical Research 25, 95-107.

SIEGEL, M. R. \& SisLeR, H. D. (1965). Site of action of cycloheximide in cells of Saccharomyces pastorianus. Three further studies on the mechanism of action and the mechanism of resistance in Saccharomyces species. Biochimica et biophysica acta 103, 558-567.
Sisler, H. D. \& Siegel, M. R. (1967). Cycloheximide and other glutarimide antibiotics. In Antibiotics, Mechanism of Action, vol. I, pp. 283-307. Edited by D. Gottlieb \& P. Shaw. New York: Springer-Verlag. Stöcklein, W. \& PiepersberG, W. (1980). Altered ribosomal protein L29 in a cycloheximide-resistant strain of Saccharomyces cerevisiae. Current Genetics 1, 177-183.

Traynor, J. D. \& NorTh, J. (1981). Role of the cytoplasmic ribosome in cycloheximide resistance in Coprinus cinereus. Heredity 46, 287.

Wilkie, D. \& LEE, B. K. (1965). Genetic analysis of actidione resistance in Saccharomyces cerevisiae. Genetical Research 6, 130-138. 